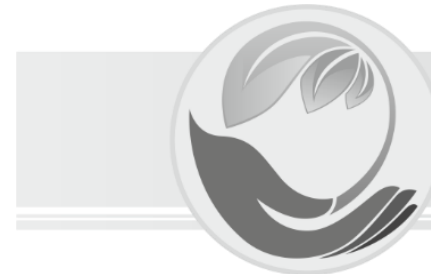

Удк 635.262

\section{Інтенсивні та екологічно ощадні технології рослинництва Intensive and ecosaving techniques in crop production}

\title{
Вплив погодних умов вегетаційного періоду, строків посадки та особливостей сорту на ріст, розвиток рослин часнику озимого
}

\author{
Л.М. Пузік ${ }^{1}$, В.К. Пузік ${ }^{2}$, М.П. Артьомов ${ }^{3}$, Л.О. Гайова ${ }^{4}$, О.І. Філімонова ${ }^{5}$ \\ 1, 2, 3 Харківський національний технічний університет сільського господарства \\ ім. Петра Василенка (м.Харків, Україна) \\ email:1 ludapusik@gmail.com; ${ }^{3}$ artiomovprof@ukr.net; ORCID: ${ }^{3}$ 0000-0002-2947-2664 \\ 4,5 Харківський національний аграрний університет ім. В.В. Докучаєва \\ (м.Харків, Україна) email: ${ }^{4}$ Gaevaaludmila9@gmail.com
}

\begin{abstract}
Проведені дослідження ставили за мету експериментальне обґрунтування деяких адаптивних елементів технології виробництва часнику озимого, яке передбачає підбір сортів та строків висаджування. Дослідження організовано у зв'язку з тим, що часник дуже поширена в усьому світі овочева культура. Через вживання часнику в організм людини потрапляють природні вітаміни, цукри, органічні кислоти, харчові волокна, що забезпечують повноцінне харчування. Під час досліджень встановлена залежність збереження рослин і строком посадки. Краще за все зберігалися зубки часнику, які були висаджені у I декаду листопада - 86,4 - 93,6\% залежно від сорту. Досліджувані сорти Любаша і Харнас перевищували контрольний сорт на 7,2 та 2\%. Значно менше всходів було одержано при висаджуванні зубків у II у декаду листопада $(77,7-84,1$ \%), ще менше у III декаду жовтня $(77,4-85,2)$. Різниця між варіантами досліду в розмірах кореневої системи до початку зимівлі в поєднанні з різницею у часі появи сходів навесні обумовило неоднакове наростання загальної маси рослин тільки до початку утворення цибулин (II - III декади квітня). коли у часнику посилюється ріст і розвиток підземних цибулин. До середини травня цей показник поступово вирівнюється за всіма варіантами. Найкоротший період від появи сходів до початку утворення підземних цибулин встановлено у сорту Любаша - від 38 до 45 діб, який порівняно з контролем був на 2 - 7 діб менший.
\end{abstract}

Ключові слова: часник, строк посадки, сортові особливості, сходи, укорінення.

Часник дуже поширена в усьому світі овочева культура. Він є одним з основних постачальників в організм людини природних вітамінів, цукрів, органічних кислот, харчових волокон, мінеральних та інших цінних речовин, що забезпечують повноцінне харчування. Це найкращий антисептик із сильною бактерицидною і фітонцидною дією, що підвищує його значимість, особливо під час вірусних епідемій $[1,2]$. Наразі пропозиції виробництва часнику суттєво відстають від зростання попиту на продукцію.

Широке впровадження часнику озимого стримується відсутністю достатньої кількості сортів, пристосованих до певних умов вирощування. Окрім того, для отримання високого врожаю культури актуальним залишається питання підбору оптимальних строків висаджування.

Врахування біологічних особливостей часнику дає змогу більш раціонально застосовувати ті чи інші елементи технології вирощування культури. Для озимих сортів часнику визначальними є строки висаджування, розмір зубків, морозо- і зимостійкість. Крім того для всіх сортів важливими є стійкість їх проти хвороб і шкідників [3].

Метою роботи $є$ експериментальне обґрунтування деяких адаптивних елементів технології виробництва часнику озимого, яке передбачає підбір сортів та строків висаджування.

Для досягнення поставленої мети вирішували такі завдання:

- визначити параметри перезимівлі, особливості росту, розвитку рослин та формування врожаю підземних цибулин залежно від сорту;

- встановити оптимальні строки висаджування часнику озимого та їх вплив на "укорінення" зубків, перезимівлю, ріст, розвиток рослин та формування врожаю підземних цибулин.

Успіх отримання високого і якісного врожаю озимого часнику багато в чому залежить від термінів посадки насіннєвого матеріалу, на які значний вплив мають природно-кліматичні умови вирощування, біологічні особливості конкретного 
сорту. Оптимальним терміном посадки часнику вважають такий, при якому посадковий матеріал, потрапивши в ґрунт, встигне до промерзання ґрунту сорормувати порівняно потужну кореневу систему з тим, щоб навесні, відразу після танення снігу, поряд з продовженням росту коренів в можливо ранні терміни почалося формування асиміляційного апарату рослини. Безсумнівно, що в кожної кліматичній зоні озимий часник після висадки зубків буде входити в такий стан в цілком певних і різні періоди осені. [4]. Для надійної зимівлі необхідно гарне вкорінення, а поява сходів з осені небажано, так як на утворення листя витрачається запасні поживні речовини, листя вбиває морозом і до весни рослини приходять виснаженими і ослабленими. Недостатнє ж укорінення часник має місце при запізненні з посадкою. Зубки зі слаборозвиненою кореневою системою до настання холодів взимку підмерзають і уражуються грибкових хвороб $[2,5]$. На підставі віщевикладеного зроблено висновок, що визначення оптимальних термінів посадки часник для кожної зони вирощування - завдання експерименту. Для озимих сортів часнику визначальними є строки висаджування, розмір зубків, морозо- і зимостійкість. Крім того для всіх сортів важливими є стійкість їх проти хвороб і шкідників [4].

Методика та умови проведення досліджень. Дослідження проводили впродовж 2017-2020 рр. на полі фермерського господарства Дружба, розташованому в східній частині Лівобережного Лісостепу України на території Харківського району.

Вивчали вплив особливостей сорта та погодних умов вегетаційного періоду на ріст, розвиток рослин часнику озимого. Польові досліди проводили згідно загальноприйнятих методик: за Б. А. Доспєховим [6], А. О. Рожковим [7]. Підготовку ґрунту під часник та догляд за рослинами здійснювали згідно зі загальноприйнятими рекомендаціями. Дослідження проводили з сортом часнику Любаша, Дюшес, та Харнас за контроль прийняли сорт «Дюшес» Спосіб розміщення рослин - стрічковий зі схемою розміщення $(10+20) x$ 45 см. Густота рослин 220 тис. шт./га. Висаджували зубки на глибину 8-10 см. Середня маса одного зубка 10 г. Норма висіву складає 2200 кг/га. Повторність в дослідах 3-х кратна [8].

Вивчали наступні строки посадки: III декада жовтня (25.10) (контроль), I декада листопада (5.11), II декада листопада (15.11). Дослідження проводились із вітчизняними сортами Любаша i Дюшес, Харнас.

У всі роки досліджень на початку настання відносного спокою рослин (повне промерзання ґрунту) 5 та 20 грудня брали ґрунтові моноліти і виділяли з них без порушення коренів проростаючи зубки часнику з метою визначення обсягу кореневої системи, кількості черешків і довжини коренів в залежності від термінів посадки та особливості сорту .

Реальний рівень забезпечення рослин вологою та теплом розрахували за допомогою гідротермічного коефіцієнту, який запропонував Селянінов [9]. Формула для розрахунку:

$$
\Gamma \mathrm{TK}=\left(\sum W \cdot 10\right) / \sum T,
$$

де: ГТК - гідротермічний коефіцієнт; $\sum W$ - сума опадів за розрахунковий період (мм); $\sum T$ - сума середньодобових температур за той же період, ${ }^{\circ} \mathrm{C}$.

Розрахований гідротермічний коефіцієнт свідчить про помірний і нестабільний характер вологозабезпеченості регіону (табл. 1).

Таблиця 1. Значення ГТК за період сходидостигання часнику озимого

\begin{tabular}{|c|c|c|c|c|c|c|c|c|c|}
\hline & \multicolumn{3}{|c|}{ Сума опадів } & \multicolumn{3}{|c|}{$\begin{array}{c}\text { Сума } \\
\text { температур, } \\
{ }^{0} \mathrm{C} \\
\end{array}$} & \multicolumn{3}{|c|}{ ГТК* } \\
\hline & \multicolumn{3}{|c|}{ роки } & \multicolumn{3}{|c|}{ роки } & \multicolumn{3}{|c|}{ роки } \\
\hline & $\frac{N}{\circ}$ & $\frac{\infty}{\delta}$ & $\frac{\sigma}{\circ}$ & $\frac{N}{\delta}$ & $\frac{\infty}{\grave{N}}$ & $\frac{\text { D }}{\grave{N}}$ & $\frac{N}{\stackrel{N}{N}}$ & $\stackrel{\infty}{\infty}$ & 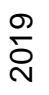 \\
\hline 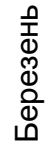 & $\stackrel{+}{\stackrel{+}{\sim}}$ & $\begin{array}{l}\text { m. } \\
\text { g" }\end{array}$ & $\stackrel{\Omega}{N}$ & గొ & 은 & 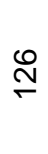 & مֵ & $\frac{N}{0^{0}}$ & $\begin{array}{l}\text { ש్ } \\
0 \\
0\end{array}$ \\
\hline 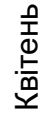 & $\bar{q}$ & $\begin{array}{l}\stackrel{\sigma}{N} \\
\stackrel{v}{-}\end{array}$ & $\begin{array}{l}0 \\
8\end{array}$ & 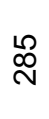 & ষ্ల & ஜ్ల & 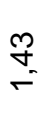 & $\begin{array}{l}0 \\
\text { లి } \\
\sigma^{\prime}\end{array}$ & $\underset{\sim}{\mathbb{N}}$ \\
\hline 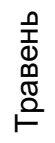 & $\begin{array}{l}0 \\
\stackrel{n}{n}\end{array}$ & 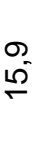 & $\stackrel{+}{\stackrel{*}{g}}$ & ָָ & คิ & ก) & $\hat{\hat{N}}$ & 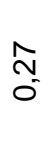 & 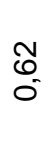 \\
\hline $\begin{array}{l}\frac{0}{1} \\
\Phi \\
\stackrel{0}{0} \\
\frac{0}{0}\end{array}$ & $\begin{array}{l}0 \\
\infty^{\infty}\end{array}$ & 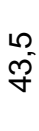 & $\stackrel{\sim}{N}$ & $\frac{N}{\sigma}$ & 옹 & ) & $\begin{array}{l}\text { ల } \\
\text { o. }\end{array}$ & $\begin{array}{l}0 \\
6 \\
0 \\
0\end{array}$ & 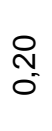 \\
\hline 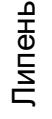 & 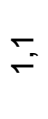 & $\hat{0}$ & 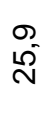 & ભ & ని & $\frac{10}{N}$ & $\begin{array}{l}8 \\
0 \\
0\end{array}$ & $\begin{array}{l}\text { లి } \\
\text { o. }\end{array}$ & $\cong$ \\
\hline
\end{tabular}

Примітка: *ГТК $\geq 1,0$ - достатнє зволоження; 0,8-1,0 - помірне зволоження; 0,6-0,7 недостатнє зволоження

Результати дослідження. Морозо- і зимостійкість часнику озимого, формування підземних цибулин залежить від формування корінців у висаджених зубків. Результатами проведених трирічних досліджень та біометричними вимірюваннями встановлено, що кількості корінців у висаджених зубків масою 6-8 г це потенційні можливості сортів.

Відмінності були вельми помітні. Рослини ранніх посадок (III декада жовтня, I декада 
листопада) мали значну перевагу у розвитку кореневої системи порівняно з більш пізніми. На наш погляд, це пов'язано з тим, що в усі роки проведення досліджень в третій декаді жовтня стояла відносно тепла (від $4,4^{\circ} \mathrm{C}$ у 2018 д до $8,3^{\circ} \mathrm{C}$ 2019 р) для часнику погода з достатнім вмістом вологи (72 - 74\% НВ) в ґрунті, В листопаді у І декаді спостерігається на рівні 3 жовтнем $\left(4,1^{\circ} \mathrm{C}\right.$, $\left.4,2^{\circ} \mathrm{C}\right)$ а у 2017 р навіть перевищувала $\left(5,2^{\circ} \mathrm{C}\right)$. Аномально теплою була I декада листопада 2017 р $з$ максимальною температурою $12,9^{\circ} \mathrm{C}$ у 2019 р. Нічні температури цього періоду були наближеними до 0 으. У II декаді листопада середньодобова коливалась від $-1,1^{\circ} \mathrm{C}$ у 2017 р. до 4 ㄷ. у 2018.У цей період у 2018. Спостерігалась максимальна денна температура - 15,6 ${ }^{\circ} \mathrm{C}$, з різкими зниженнями температури в нічні години від $-2,7^{\circ} \mathrm{C}$. у 2018 р. до $-6^{\circ} \mathrm{C}$ у 2017 p.

На час замерзання ґрунту і припинення ростових процесів першого терміну посадки кількість корінців одного зубки 39,3 - 41,1 шт, довжина одного кореня - 10,3-10,2 мм, у варіанті другого терміну посадки що достовірно більше, ніж у варіанті при посадці 15 листопада ці показники значно нижче відповідно 18,7 - 20,6 шт. і 81,9 - 84,3 мм (табл. 2).

Таблиця 2. Параметри кореневої системи в сортів часнику озимого стрілкуючого у період від висаджування до замерзання ґрунту (середнє за 2017-2019 рр.)

\begin{tabular}{|c|c|c|c|c|}
\hline Сорт & 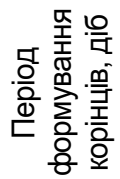 & 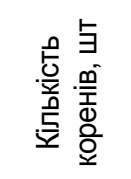 & 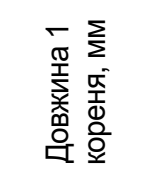 & 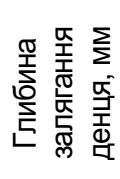 \\
\hline \multicolumn{5}{|c|}{ III декада жовтня } \\
\hline $\begin{array}{c}\text { Дюшес } \\
\text { (контроль) }\end{array}$ & $30-58$ & $39,4 \pm 3,3$ & $155,7 \pm 5,0$ & $100 \pm 7$ \\
\hline Любаша & $30-58$ & $42,3 \pm 4,5$ & $163,7 \pm 4,8$ & $103 \pm 8$ \\
\hline Харнас & $30-58$ & $41,1 \pm 4,9$ & $162,1 \pm 5,8$ & $102 \pm 7$ \\
\hline У середньому & $30-58$ & $40,9 \pm 1,5$ & $160,1 \pm 4,0$ & $102 \pm 7$ \\
\hline \multicolumn{5}{|c|}{ I декада листопада } \\
\hline $\begin{array}{c}\text { Дюшес } \\
\text { (контроль) }\end{array}$ & $21-45$ & $29,4 \pm 1,7$ & $89,9 \pm 2,2$ & $78 \pm 9$ \\
\hline Любаша & $21-45$ & $32,4 \pm 3,5$ & $94,1 \pm 4,7$ & $85 \pm 8$ \\
\hline Харнас & $21-45$ & $31,7 \pm 3,3$ & $90,1 \pm 5,0$ & $82 \pm 7$ \\
\hline У середньому & $21-45$ & $31,2 \pm 1,5$ & $91,4 \pm 2,1$ & $82 \pm 4$ \\
\hline \multicolumn{5}{|c|}{ II декада листопада } \\
\hline $\begin{array}{c}\text { Дюшес } \\
\text { (контроль) }\end{array}$ & $10-36$ & $18,7 \pm 2,9$ & $81,9 \pm 3,8$ & $58 \pm 8$ \\
\hline Любаша & $10-36$ & $20,6 \pm 3,7$ & $84,3 \pm 5,5$ & $62 \pm 7$ \\
\hline Харнас & $10-36$ & $18,9 \pm 2,5$ & $83,5 \pm 2,5$ & $59 \pm 6$ \\
\hline У середньому & $10-36$ & $19,4 \pm 1,0$ & $83,2 \pm 1,2$ & $60 \pm 2$ \\
\hline
\end{tabular}

Примітка: Аналізи проводили, коли знижувалась середньодобова температура до мінус $3{ }^{\circ} \mathrm{C}$ : 25 листопада (2017 р), 5 грудня (2018 р) та
20 грудня (2019 р). Період фрормування корінців 35, 48 і 66 діб.

Так, у середньому за період від висаджування зубків часнику озимого стрілкуючого (І декада жовтня) до замерзання ґрунту найбільшу кількість корінців утворював сорт Любаша - 42,3 4,5 шт. Він перевищував контроль (Дюшес) на 2,9 шт. У сорту Харнас кількість корінців становила $41,1 \pm 4,9$, що більше контролю на 1,7 шт. (табл. 2).

За період висаджування зубків часнику озимого у I декаді листопада кількість коренів зменшилася у середньому на 23,4 - 25,6 \%. Зменшення кількості коренів залежало від особливостей сорту , у сорту Любаша - 23,4 \%, Харнас $24,3 \%$, а у контрольному варіанту $-25,6 \%$.

Підвищеною стійкістю до мінусових температур характеризувалися Любаша та Харнас, у яких глибина залягання денця укорінених зубків була - від 62 - 103 та 59 -102 і 94 мм. Залежно від строку посадки.

Таким чином, ранні строки посадки часнику озимого формують біль міцну кореневу систему, що повинно благоприємно впливати на зимівлю рослин і дружнє відростання їх навесні. Протягом зимового періоду укорінені зубки сортів часнику озимого продовжували свій ріст і розвиток. Підтвердженням цього були біометричні вимірювання, які проводили на рослинах після розмерзання ґрунту. Результати біометричного спостереження проведені навесні (I декада березня) свідчать, що існує залежність збереження рослин і строком посадки (табл. 3).

Таблиця 3. Збереженість рослин часнику озимого після зимівлі залежно від строків посадки, \% (2017 - 2019pр).

\begin{tabular}{|c|c|c|c|}
\hline \multirow{2}{*}{ Сорт } & \multicolumn{3}{|c|}{ Строк посадки } \\
\cline { 2 - 4 } & $\begin{array}{c}\text { І декада } \\
\text { жовтня }\end{array}$ & $\begin{array}{c}\text { І декада } \\
\text { листопада }\end{array}$ & $\begin{array}{c}\text { II декада } \\
\text { листопада }\end{array}$ \\
\hline $\begin{array}{c}\text { Дюшес } \\
\text { (контроль) }\end{array}$ & 78,2 & 86,4 & 77,7 \\
\hline Любаша & 85,2 & 93,6 & 84,1 \\
\hline Харнас & 77,4 & 88,4 & 81,2 \\
\hline
\end{tabular}

При цьому краще за все зберігалися зубки часнику, які були висаджені у I декаду листопада - 86,4 - 93,6\% залежно від сорту. Необхідно відмітити, що досліджувані сорти Любаша і Харнас перевищували контрольний сорт на 7,2 та $2 \%$. Значно менше всходів було одержано при висаджуванні зубків у II у декаду листопада $(77,7-84,1 \%)$, ще менше у III декаду жовтня $(77,4$ - 85,2). Очевидно, що зубки посаджені раніше встигали витрачати на утворення коренів i проростків (в 2018, 2019 рр.) 6-8 см біль поживних речовин, тому знижувалась їх зимостійкість.

Протягом всього вегетаційного періоду за роки досліджень зберігалась різниця у наростанні лист- 
кової частини в часнику озимого залежно від строку посадки та погодних умов вегетаційного періоду.

Навесні одиничні сходи спостерігали залежно від строків посадки 27.02, 1.03 та 3.03. У 2017p, масові сходи в досліджуваних сортах з'являлися 5.03 - 7.03 при посадці у III декаду жовтня, пізні строки посадки забезпечили масові сходи 8.03 - 10.03 (І декада листопада) та 10.03(посадка у II декаду листопада). У 2018 р, температура якого була значно холодніша за температуру цього періоду 2017 р. сходи з'явились на 4 - 6 діб пізніше, а у 2019p на 3 - 7 діб раніше. Cеред сортів також була відмінність Поява сходів сорту Любаша спостерігалась на 2-3 доби раніше. У проростаючих зубків перший листок короткий $-0,5-1,5 \mathrm{~cm}$.

Другий листок утворювався у сорту Любаша та Харнас на 2-3 доби раніше, порівняно з контролем. Починаючи 3 третього, листок набуває нормальної, характерної для сорту довжини і ширини. Другий листок за величиною займає проміжне місце між першим і третім. Четвертий листок формувався на 7- 13 діб, шостий листок на 8-12 діб раніше контролю. Довжина та ширина листкової пластинки (асиміляційний апарат) найбільшою була у часнику при жовтневій посадці на початку вегетаційного періоду (другий листок) i різнилась залежно від погодних умов. Найменшими були листові пластинки рослин пізнього строку садіння - 50 - 53 мм (табл.4).

Таблиця 4. Довжина листкової пластинки у сортів часнику озимого стрілкуючого (середнє за 2017-2019 рр.)

\begin{tabular}{|c|c|c|c|c|}
\hline \multirow{2}{*}{ Сорт } & \multicolumn{4}{|c|}{ 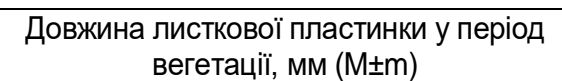 } \\
\hline & другий & $\begin{array}{l}\text { четвер- } \\
\text { тий }\end{array}$ & шостий & восьмий \\
\hline \multicolumn{5}{|c|}{ III декада жовтня } \\
\hline $\begin{array}{c}\text { Дюшес } \\
\text { (контроль) }\end{array}$ & $50 \pm 2,0$ & $105 \pm 4,0$ & $172 \pm 5,0$ & $197 \pm 5,0$ \\
\hline Любаша & $53 \pm 3,0$ & $113 \pm 5,0$ & $187 \pm 8,5$ & $205 \pm 6,0$ \\
\hline Харнас & $52 \pm 3,5$ & $109 \pm 10$ & $175 \pm 4,5$ & $201 \pm 4,0$ \\
\hline \multicolumn{5}{|c|}{ I декада листопада } \\
\hline $\begin{array}{c}\text { Дюшес } \\
\text { (контроль) }\end{array}$ & $46 \pm 2,5$ & $102 \pm 4,0$ & $176 \pm 8,0$ & $209 \pm 12$ \\
\hline Любаша & $49 \pm 3,0$ & $111 \pm 5,0$ & $176 \pm 4,0$ & $211 \pm 9,0$ \\
\hline Харнас & $47 \pm 3,5$ & $105 \pm 2,0$ & $173 \pm 3,5$ & $208 \pm 2,5$ \\
\hline \multicolumn{5}{|c|}{ II декада листопада } \\
\hline $\begin{array}{c}\text { Дюшес } \\
\text { (контроль) }\end{array}$ & $37 \pm 2,5$ & $100 \pm 6,0$ & $139 \pm 4,0$ & $187 \pm 4,5$ \\
\hline Любаша & $38 \pm 4,0$ & $109 \pm 11$ & $145 \pm 4.0$ & $200 \pm 6,0$ \\
\hline Харнас & $38 \pm 3,0$ & $105 \pm 11$ & $142 \pm 5,0$ & $196 \pm 3,5$ \\
\hline
\end{tabular}

Розмір листків - сортова особливість часнику озимого. Найбільші довжина листкової пластинки була у сорту Любаша - 50 - 56 мм. За довжиною 4 листка (113 \pm 5 мм) також виділявся сорт Любаша і перевищував контрольний варіант у середньому на 4-8 мм. При цьому спостерігається інтенсивне наростання довжини листкової пластинки - 105\% порівняно з довжиною другого листка. При утворенні 6 листка темпи збільшення розмірів довжини листкової пластинки на 63\% порівняно $з$ довжиною четвертого листка і становлять у сорту Любаша $187 \pm 8,5$ мм. При другому та третьому строках садіння темпи наростання листкової пластинки менш інтенсивні. Довжина четвертого листка збільшується на 39 і 35 \% відповідно, а восьмого листка - на $20-30 \%$

Розміри шостого листка вирівнюються незалежно від строків посадки. В подальшому по всім строкам посадки іде динамічне наростання асиміляційного апарату і триває до початку усихання верхньої частини листа.

У період вегетації ширина листків сортів характеризувала інтенсивність росту надземної частини рослин, величина яких змінювалася залежно від наростання листків (табл. 5). Ширина листкової пластинки четвертого листка порівняно 3 другим збільшувалась на $5 \%$, шостого порівняно з четвертим на $14 \%$, восьмого порівняно з шостим на $12 \%$ при жовтневому садінні.

Таблиця 5. Ширина листкової пластинки у сортів часнику озимого стрілкуючого (середнє за 2005-2007 рр.)

\begin{tabular}{|c|c|c|c|c|}
\hline \multirow{2}{*}{ Сорт } & \multicolumn{4}{|c|}{ Ширина листкової пластинки у період } \\
\cline { 2 - 5 } & другий & $\begin{array}{c}\text { четвер- } \\
\text { тий }\end{array}$ & $\begin{array}{c}\text { шос- } \\
\text { тий }\end{array}$ & $\begin{array}{c}\text { вось- } \\
\text { мий }\end{array}$ \\
\hline \multicolumn{5}{|c|}{ II декада жовтня } \\
\hline $\begin{array}{c}\text { Дюшес } \\
\text { (контроль) }\end{array}$ & $11 \pm 1,5$ & $13 \pm 1,5$ & $16 \pm 3,5$ & $17 \pm 3,5$ \\
\hline Любаша & $14 \pm 1,5$ & $17 \pm 1,0$ & $19 \pm 1,5$ & $22 \pm 1,0$ \\
\hline Харнас & $13 \pm 1,0$ & $16 \pm 1,0$ & $18 \pm 1,5$ & $21 \pm 1,5$ \\
\hline \multicolumn{5}{|c|}{ І декада листопада } \\
\hline $\begin{array}{c}\text { Дюшес } \\
\text { (контроль) }\end{array}$ & $10 \pm 2,0$ & $12 \pm 1,0$ & $15 \pm 1,0$ & $19 \pm 1,0$ \\
\hline Любаша & $13 \pm 1,5$ & $13 \pm 1,0$ & $16 \pm 1,0$ & $20 \pm 1,0$ \\
\hline Харнас & $11 \pm 0,5$ & $12 \pm 0,5$ & $16 \pm 0,5$ & $20 \pm 0,5$ \\
\hline \multicolumn{5}{|c|}{ декада листопада } \\
\hline $\begin{array}{c}\text { Дюшес } \\
\text { контроль) }\end{array} 10 \pm 1,5$ & $12 \pm 1,5$ & $14,1,5$ & $18 \pm 1,0$ \\
\hline Любаша & $11 \pm 1,0$ & $11 \pm 1,0$ & $16 \pm 1,5$ & $20 \pm 2,0$ \\
\hline Харнас & $11 \pm 1,5$ & $11 \pm 1,0$ & $15 \pm 1,5$ & $19 \pm 2,0$ \\
\hline
\end{tabular}

При садінні у I і II декади листопада інтенсивність збільшення ширини листкової пластинки становило 3, 30, 26\% та 4,5, 32, 21 \% відповідно

Різниця між варіантами досліду в розмірах кореневої системи до початку зимівлі в поєднанні з різницею у часі появи сходів навесні обумовило неоднакове наростання загальної маси рослин тільки до початку утворення цибулин (II - III декади квітня). Далі, коли у часнику посилюється ріст і розвиток підземних цибулин (до середини травня) цей показник поступово вирівнюється по всім варіантам. На наш погляд це можна пояснити тим, що з першої декади квітня рослини всіх 
строків садіння перейшли на особове кореневе забезпечення мінеральними речовинами.

Сорти часнику озимого стрілкуючого відрізнялися не тільки за наростанням надземної частини рослин, а й за формуванням підземних цибулин. Слід зазначити, що дата появи сходів впливала на початок утворення підземних цибулин. Так, у 2017 р. раніше формувалися підземні цибулини в сорту Любаша на 43-у - 45-удобу, що на 2-3 доби швидше за контроль. Раніше на 2 доби - сорт Харнас. У 2018 р. спостерігалась аналогічна закономірність, утворення підземних цибулин відбувалося у сорту Любаша на 40-47 добу залежно від строку посадки зубків. У 2019 р утворення підземних цибулин становило 38 - 46 діб.

Таким чином, найкоротший період від появи сходів до початку утворення підземних цибулин встановлено у сорту Любаша - від 38 до 45 діб, який порівняно з контролем був на 2 - 7 діб менший.

Висновки. 1. Встановлена залежність збереження рослин і строком посадки. Краще за все зберігалися зубки часнику, які були висаджені у I декаду листопада - 86,4 - 93,6\% залежно від сорту. Досліджувані сорти Любаша і Харнас перевищували контрольний сорт на 7,2 та 2\%. Значно менше всходів було одержано при висаджуванні зубків у II у декаду листопада (77,7-84,1\%), ще менше у III декаду жовтня $(77,4-85,2)$.

2. Різниця між варіантами досліду в розмірах кореневої системи до початку зимівлі в поєднанні з різницею у часі появи сходів навесні обумовило неоднакове наростання загальної маси рослин тільки до початку утворення цибулин (II - III декади квітня). Далі, коли у часнику посилюється ріст і розвиток підземних цибулин (до середини травня) цей показник поступово вирівнюється по всім варіантам.

Найкоротший період від появи сходів до початку утворення підземних цибулин встановлено у сорту Любаша - від 38 до 45 діб, який порівняно з контролем був на 2-7 діб менший.

\section{Література:}

1. Бобось І.М., Горох Т.О. Господарсько-біологічна оцінка сортів часнику озимого (Allium sativum L.), вирощених в умовах Лісостепу України /Науковий вісник Національного університету біоресурсів і природокористування України. - К., 2011. Частина 1, серія «Агрономія» - Вип. 162. C. 230 - 235.

2. Барабаш О.Ю. Біологічні особливості часнику як основа сучасних технологій його вирощування / О.Ю. Барабаш // Науковий збірник Львівського національного аграрного університету: матеріали Міжнар. наук.-практ. форуму, 21-24 вересня 2011 р. - Львів, 2011. - С. 172 - 175

3. Капустіна Л.І. Основні господарсько-цінні ознаки нових сортів часнику озимого в умовах Лісостепу України / Л.І.Капустіна, І.А. Недялкова.-
Овочівництво і баштанництво, 2006.-Вип.52.C.392 - 397.

4. Бобось І. М. Вплив строків сівби на урожайність сортів редьки лоба / І. Бобось, І. Брейтер // Sworld Научные труды. - Иваново: Научный мир, 2015. №2.(39). _ Том 17. - С. 42 - 50. доступно http://elibrary.ru/item.asp?id=23736486

5. Барабаш О.Ю. Біологічні основи овочівництва /Барабаш О.Ю., Тараненко Л.К., Сич З.Д. К. : Арістей, 2005. - 350 с.

6. Доспехов Б. А. Методика полевого опыта (с основами статистической обработки результатов исследований). Изд. 5-е., доп. и перераб. Москва: Агропромиздат, 1985. 351 с.

7. Рожков А. О. та ін. Дослідна справа в агрономії: навч. посібник: у 2 кн. Кн. 1. Теоретичні аспекти дослідної справи: за ред. А. О. Рожкова. Харків: Майдан, 2016. 316 с.

8. Сучасні технології в овочівництві: за ред. К. І. Яковенка. Харків, 2001. 120 с.

9. Селянинов Г. Т. О сельскохозяйственной оценке климата. Труды по с.-х. метеорологии. 1928. - Вып. 20. - С. 165 - 177.

\section{References:}

1. Bobos, I. M. and Goroh, T. O. (2011) 'Gospodarsko-blologlchna otsInka sortlv chasniku ozimogo (Allium sativum L.), viroschenih v umovah LIsostepu UkraYini', Naukoviy vlsnik Natslonalnogo unlversitetu bloresurslv I prirodokoristuvannya UkraYini. - K., "Agronomlya», 162(1), pp. 230 - 235.

2. Barabash, O. Y. (2011) Blologlchnl osoblivostl chasniku yak osnova suchasnih tehnologly yogo viroschuvannya, Naukoviy zblrnik Lvlvskogo natslonalnogo agrarnogo unlversitetu: materlali Mlzhnar. nauk.-prakt. forumu, Lvlv, pp. 172 - 175.

3. Kapustlna, L. I. and Nedyalkova, I. A. (2006) 'Osnovnl gospodarsko-tsInnl oznaki novih sortlv chasniku ozimogo v umovah LIsostepu UkraYini', Ovochlvnitstvo I bashtannitstvo, 52, pp. 392-397.

4. Bobos, I. M. and Breyter, I. (2015) 'Vpliv stroklv slvbi na urozhaynlst sortlv redki loba', Sworld Nauchnyie trudyi. - Ivanovo: Nauchnyiy mir, 2(17), pp. 4250. Available at: http://elibrary.ru/item.asp?id=23736486.

5. Barabash, O. Y. and Taranenko, L. K. (2005) 'Blologlchnl osnovi ovochlvnitstva', Sich Z.D. - K. : Arlstey, p. 350.

6. Dospehov, B. A. (1985) Metodika polevogo opyita (s osnovami statisticheskoy obrabotki rezultatov issledovaniy). Agropromiz, Izd. 5-e., dop. i pererab. Agropromiz. Moskva. P. 351

7. Rozhkov, A.O. ta I. (2016) 'Doslldna sprava v agronomlYi: navch. poslbnik', Teoretichnl aspekti doslldnoYi s pravi: za red. A.O.Rozhkova. 2(1), p. 316.

8. Yakovenka, K. I. (2001) Suchasnl tehnologIYi v ovochlvnitstvl: za red. K. I. Yakovenka. Harklv. p.120

9. Selyaninov, G.T. (1928) 'O selskohozyaystvennoy otsenke klimata', Trudyi po s.-h. meteorologii., 20, pp. 165 - 177. 
Аннотация

\section{Влияние погодных условий вегетационного периода, сроков посадки и особенностей сорта на рост, развитие растений чеснока озимого}

\section{Л.М. Пузик, В.К. Пузик, Н.П. Артёмов, Л.А. Гаевая, Е.И. Филимонова}

Проведенные исследования ставили целью экспериментальное обоснование некоторых адаптивных элементов технологии производства чеснока озимого, которые предусматривают подбор сортов и сроков посадки. Исследование организовано в связи с тем, что чеснок очень распространенная во всем мире овощная культура. При употреблении чеснока в организм человека попадают природные витамины, сахара, органические кислоты, пищевые волокна, которые обеспечивают полноценное питание. Во время исследований установлена зависимость между сохраненостью растений и сроком посадки. Лучше всего сохранялись зубки чеснока, которые были высажены в І декаду ноября - 86,4 - 93,6\% в зависимости от сорта. Исследуемые сорта Любаша и Харнас превышали контрольный сорт на 7,2 и $2 \%$. Значительно меньше всходов было получено при посадке зубков во II в декаду ноября (77,7 $84,1 \%)$, еще меньше в III декаду октября (77,4 - 85,2\%). Разница между вариантами опыта в размерах корневой системы до начала зимовки в сочетании с разницей во времени появления всходов весной обусловило неодинаковое нарастание общей массы растений только до начала образования луковиц (II - III декады апреля). когда у чеснока усиливается рост и развитие подземных луковиц. К середине мая этот показатель постепенно выравнивается по всем вариантам. Самый короткий период от появления всходов до начала образования подземных луковиц установлен у сорта Любаша от 38 до 45 суток, который по сравнению с контролем был на 2 - 7 суток меньше.

Ключевые слова: чеснок, срок посадки, сортовые особенности, всходы, укоренение.

Abstrsct

\section{Influence of weather conditions of the vegetation period, terms of planting and features of a grade on growth, development of plants of winter garlic}

\section{L.M. Pusik, V.K. Pusik, N.P. Artiomov, L.A. Gaevaya, E.I. Filimonova}

The conducted research aimed at experimental substantiation of some adaptive elements of winter garlic production technology, which provides for the selection of varieties and timing of planting. The dependence of plant preservation and planting period is established. Garlic cloves, which were planted in the first decade of November, were best preserved - $86.4-93.6 \%$, depending on the variety. The studied cultivars Lyubasha and Harnas exceeded the control cultivar by 7.2 and $2 \%$. Significantly fewer seedlings were obtained when planting teeth in the second decade of November (77.7-84.1\%), even less in the third decade of October (77.4-85.2). The difference between the variants of the experiment in the size of the root system before winter in combination with the difference in the time of emergence in the spring caused a different increase in total plant mass only before the formation of bulbs (II - III decades of April). oil in garlic increases the growth and development of underground bulbs By mid-May, this figure is gradually equalized for all options. The shortest period from the emergence of seedlings to the beginning of the formation of underground bulbs was found in the variety Lyubasha - from 38 to 45 days, which compared to the control was 2-7 days less.

Keywords: garlic, planting term, varietal features, seedlings, rooting.

Бібліографрічне посилання/ Bibliography citation: Harvard

Pusik, L. M. et al. (2020) 'Influence of weather conditions of the vegetation period, terms of planting and features of a grade on growth, development of plants of winter garlic', Engineering of nature management, (2(16)), pp. $19-24$.

Подано до редакції / Received: 12.08.2020 